\title{
INTEGRASI TEKNOLOGI DALAM PEMBELAJARAN IMPLEMENTASI PEMBELAJARAN ILMU TEKNOLOGI DAN MASYARAKAT
}

\author{
Khomarudin, Na'imah \\ IAIN Syekh Nurjati Cirebon, SMA Plus YAKPI Cirebon \\ oemarbakrie0231@gmail.com,umi_izzul_alya@yahoo.com
}

\begin{abstract}
Abstrak
Penelitian ini bertujuan untuk mendiskripsikan peranan dan pemanfaatan teknologi digital dalam pembelajaran dan masyarakat di Era Industri 4.0. Bahasan integrasi tersebut ditinjau dari implementasi dalam pembelajaran ilmu teknologi dan masyarakat. Prinsip dasar dalam integrasi ilmu teknologi dan dalam pembelajaran yaitu penggunaan teknologi tidak menyebabkan menurunya pemahaman konseptual atau menggantikan peranan intuisi mahasiswa dan masyarakat. Sebaliknya, teknologi bertujuan untuk meningkatkan pemahaman konseptual mahasiswa dan mengembangkan kemampuan mahasiswa dalam berkomunikasi dalam menjalankankan peranya baik di dunia pendidikan ataupun di masyarakat.

Penelitian ini menggunakan pendekatan deskriptif kualitatif. Penelitian dilakukan terhadap mahasiswa yang sedang mengikuti perkuliahan pada mata kuliah Ilmu Teknologi dan Masyarakat. Peneliti menggunakan angket sebagai instrumen untuk mendapatkan data. Peneliti menganalisa hasil data tersebut dengan mengelompokkan, display data, menganalisa kemudian menyimpulkan.

Hasil penelitian menunjukan bahwa implementasi teknologi digital dalam pembelajaran yaitu: (1) Teknologi yang berfungsi sebagai alternatif alat bantu media pembelajaran untuk melakukan kegiatan pembelajaran; (2) Teknologi sebagai asah soft skills, yaitu teknologi yang berfungsi sebagai lingkungan belajar untuk mengasah keterampilan tertentu bagi peserta didik; (3) Teknologi untuk membantu kegiatan masyarakat, yaitu teknologi digital yang berfungsi sebagai alat bantu dalam meringankan pekerjaan masyarakat. Itulah ketiga temuan yang bisa disimpulkan dari pembelajaran Ilmu Teknologi dan Masyarakat.
\end{abstract}

Kata kunci: Teknologi Pembelajaran; Integrasi Teknologi; Peranan Teknologi dalam masyarakat.

\begin{abstract}
This study aims to describe the role and use of digital technology in learning and society in the Industrial Age 4.0. The discussion of integration is viewed from the implementation in learning technology and society. The basic principle in the integration of technology science and in learning, namely the use of technology does not cause a decrease in conceptual understanding or replace the role of student and community intuition. Conversely, technology aims to increase students' conceptual understanding and develop students' ability to communicate in carrying out their roles both in the world of education and in society.

This research use desciptive qualitative approach. The research was conducted on students who were taking lectures in the Technology and Society Science course. Researcher used a questionnaire as an instrument to obtain data.
\end{abstract}

Jurnal Edueksos Vol IX, No. 2, Desember 2020

The journal of social and economics education 
Researcher analyzed the results of these data by grouping, displaying data, analyzing then concluding.

The results showed that the implementation of digital technology in learning, namely: (1) Technology that serves as an alternative tool for learning media to carry out learning activities; (2) Technology as a soft skill sharpener, namely technology that functions as a learning environment to hone certain skills for students; (3) Technology to assist community activities, namely digital technology which functions as an aid in easing community work. Those are the three findings that can be concluded from learning Technology Science and Society.

Key words: Learning Technology; Technology Integration; Role of Technology in society.

\section{A. PENDAHULUAN}

Tingginya teknologi yang dibicarakan di seluruh sudut bumi akhir-akhir ini, telah menyebabkan perubahan gaya hidup, cara belajar, cara komukasi, dan cara bekerja manusia di segala lini dalam tatanan peradaban manusia. Bagian dari kekhasan dari teknologi adalah kecepatan, semua pekerjaan dan kegiatan dapat dilakukan dengan cepat. Sehingga setiap manusia di era teknologi ini menuntut segala sesuatu dengan cepat. Ciri lain yang tidak kalah pentingnya adalah teknologi itu menarik dan menyenangkan, sehingga banyak orang yang bermain dalam bidang teknologi selalu senang bahkan terkadang sampai lupa waktu.

Di masa digital ini, keunggulan teknologi dapat dan memungkinkan komunikasi dan interaksi yang begitu cepat tanpa di batasi oleh ruang dan waktu. Berbeda dengan era sebelumnya, kemajuan suatu bangsa dalam era informasi/ global sangat tergantung pada kemampuan warganya dalam memanfaatkan pengetahuan untuk meningkatkan produktifitas dan kreatifitas. Orang yang menguasai pengetahuan dan teknologi akan mampu berkompetisi dalam persaingan di era teknologi global. Maka dari itu, berbagai negara berkompetisi bagaimana bisa mengintegrasikan teknologi informasi dan komunikasi dalam berbagai lini dalam kehidupan bernegara, utamanya aspek pendidikan. Martinus (2017) berpendapat bahwa perubahan dalam pola dan proses pembelajaran sangat dibutuhkan untuk dapat memberikan inovasi dalam mengikuti dinamika perubahan dan perkembangan zaman yang begitu masiv yang dipengaruhi oleh pertumbuhan dan perkembangan teknologi. 
Asrizal (2013) mengemukakan bahwa kehidupan dalam masyarakat telah berkembang seiring dengan perkembangan Sains dan Teknologi. Kemajuan Sains dan teknologi menuntut manusia semakin bekerja keras untuk menyesuaikan diri dalam berbagai aspek kehidupan. Eksistensi dalam aspek pendidikan akan menentukan keberhasilan kehidupan manusia yang penuh tantangan dan persaingan. Proses pendidikan seharusnya mampu membentuk manusia yang melek terhadap Sains dan Teknologi secara utuh.

Dari pendapat di atas, saya menyimpulkan dalam bidang pendidikan, Teknologi dan Informasi ini perlu di integrasikan dan digunakan dalam berbagai dimensi. Dalam bidang pembelajaran, penelitian, dan metode pembelajaran. Dalam bidang pendidikan, penggunaan teknologi sangat diperlukan untuk membantu meningkatkan dan mencapai mutu pendidikan. Pendidikan sangat membutuhkan sentuhan teknologi dan informasi dalam proses pembelajarannya sehingga dapat menghadirkan peningkatan karakter.

Suryadi (2007) mengungkapkan penggunaan teknologi mempunyai kelebihan dalam proses pembelajaran, yaitu membantu dan memudahkan siswa, juga membuat siswa merasakan kemanfaatan dari teknologi karena siswa dapat menangkap dengan berbagai warna, pilihan gambar, suara, video, dan sesuatu yang tersedia dalam media tersebut. Hal seperti ini dan memberikan kenyamanan dan penasaran siswa yang sebenarnya menjadi salah satu faktor yang sangat urgen dan esensial untuk mencapai efektivitas belajar. Di sini teknologi mampu membangkitkan emosi positif dalam proses belajar.

Oleh karena itu, artikel ini bertujuan untuk mendeskripsikan secara general prinsip dan pertimbangan dalam penerapan teknologi digital dalam Mata Kuliah Ilmu Teknologi dan Masyarakat, yaitu menjawab tiga pertanyaan berikut ini: (1) Bagaimana peran teknologi dalam pembelajaran, (2) Bagaimana respon mahasiswa terhadap penggunaan teknologi dan penerapanya dalam pembelajaran, (3) Bagaimana peran teknologi dalam kehidupan masyarakat?

Derasnya kemajuan teknologi tidak bisa dipungkiri akan semakin memanjakan manusia, seperti dalam hal berkomunikasi. Interaksi dan komunikasi yang terjadi dengan munculnya bantuan teknologi menjadi semakin mudah dan beragam bahkan relatif efesien. Teknologi yang dimaksud antara lain dan yang 
sekarang sedang marak bahkan menjadi fenomena adalah website, blog, micro blogging site, electronic mail (e-mail), Yahoo Messenger (YM), Google talk (Gtalk), google classroom, edmodo, kahoot, scoology, serta yang saat ini sedang di gandrungi semua kalangan adalah jejaring sosial.

Dalam wikipedia menuliskan bahwa teknologi Informasi dan komunikasi adalah ilmu yang mempelajari tentang desain, pengembangan, implementasi, manajemen sistem informasi yang berbasiskan komputer, khususnya aplikasi perangkat lunak dan berat. Berdasarkan makna tersebut, Teknologi Informasi dan komunikasi berhubungan erat dengan pemanfaatn komputer secara elektronik dan perangkat yang ada dalam komputer untuk mendesain, menyimpan, memproses, dan dapat mengambil kembali terkait informasi secara aman.

Degeng (2004) menyampaikan mutu dari pembelajaran dapat di lihat dari dua segi yaitu segi proses dan hasil pembelajaran. Untuk memperbaiki mutu dari proses dan hasil harus mengarah kepada munculnya inisiatif baik dari peserta didik ataupun dari pendidiknya sendiri.

Melanjutkan dengan proses pembelajaran seperti apa yang diutarakan oleh Degeng (2004), Miarso (2004) menambahkan elemen yang berpengaruh dalam mendukung tercapainya pembelajaran yang bermutu adalah pemanfaatan dan penggunaan teknologi dalam proses pembelajaran.

Suyatno (2016) mengungkapkan secara teoretis TIK memainkan peran yang sangat luar biasa untuk mendukung terjadinya proses belajar yang baik. Berikut ini beberapa hal positif yang dapat terlahir dari penggabungan TIK dalam proses pembelajaran; Aktif, peserta didik dapat berperan secara aktif dengan adanya pemanfaatan teknologi dalam proses belajar yang berkesan dan berarti. Penggunaan TIK seperti pembuatan presentasi dengan powerpoint, pelaporan dengan Ms Word, browsing internet akan membuat peserta lebih aktif.

Suryadi (2007) mengungkapkan perubahan yang cepat pada masa sekarang ini disebabkan terutama oleh kemajuan teknologi. Teknologi meruapakan dimensi perubahan, yaitu menjadikan perubahan yang sangat massiv, dan berkembang begitu cepat dan intensif. Berkaitan dengan ranah pendidikan dan pengetahuan, perkembangan dan perubahan ini sedang berjalan dengan dua dimensi, yaitu mentrnaformasi kinerja otak modern yang mencengangkan dengan kekuatan 
informasi dan pengetahuan yang dapat diakses secara cepat dan mudah melalui perantara teknologi informasi dan komunikasi (ICT).

Pertumbuhan teknologi digital di era Industri 4.0 saat ini telah membawa perubahan dan mempengaruhi berbagai aspek kehidupan manusia, termasuk di bidang pendidikan. Hoyles \& Lagrange (2010) menegaskan bahwa teknologi digital adalah hal yang paling mempengaruhi sistem pendidikan di dunia saat ini. Hal ini disebebkan karena aspek efektivitas, efisiensi dan daya tarik yang ditawarkan oleh pembelajaran berbasis teknologi digital.

Dodi Nandika et all (2007: 11) mendeskripsikan Teknologi Informasi dan Komunikasi merupakan media yang bisa dimanfaatkan untuk menyampaikan dengan cara yang menarik dan inovatif untuk menyediakan pembelajaran long life education dengan akses global yang sangat mudah terhadap informasi terkait dengan pengetahuan dan pembelajaran. Dengan berbagai keuntungan sebagai berikut:

Konstruktif, peserta didik dapat mengeloboarasikan ilmu baru ke dalam pengalaman yang telah dialami sebelumnya untuk mndalami makna atau penasaran dan skeptisme yang tersirat selama ini dalam benaknya. Dengan penggunaan bermacam-macam Teknologi Informasi dan Komunikasi, masingmasing peserta didik dapat mengeksplor pengetahuannya sesuai kemampuan dalam penguasaan Teknolgi Informasi dan Komunikasi.

Kolaborasi, peserta didik di dalam sebuah komunitas atau organisai yang saling berkomunikasi, tukar pikiran, kritik atau dengan ekperimenya, saling menasehati dan memberikan saran dan kritik untuk sesama anggota kelompoknya. Intensif, dengan pendekatan TIK peserta didik dengan semangat dan antusias berusaha denagn gigihnya untuk sampai pada tujuan yang ditargetkan. Peserta akan lebih mudah dalam memahami materi didik dan mencapai tujuan pembelajaran. Interaktif, proses belajar mengajar adalah sebuah praktek sosial dan komunikasi yang mana para peserta didik mendapatkan sebuah pemahaman dan informasi dari proses komunikasi tersbut baik di dalam ruangan kelas secara langsung ataupun di luar kelas melalui mobile phone, chatting, zoom, dan sms.

Kontektual, kegiatan pembelajaran di harapkan mengarah pada proses pembelajaran yang penuh dengan makna dengan sebuah pendekatan "problem- 
based atau case-based learning". Pada era di gital, mengintegrasikan Teknologi Informasi dan Komunikasi dalam pembelajaran merupakan tuntutan yang harus disiapkan di masa kini. Berbagai model pengembangan dalam mengintegrasikan Tekonologi dalam pembelajaran di kembangkan. Para expert mengembangkan pembelajran berintegrasi dengan teknolgi dengan berbagai model (Woodbridge: 2004). Beberapa catatan penting dari model tersebut adalah sebagai berikut.

1. Teknologi Informasi dan Komunikasi (ICT) mempunyai peran dalam tiga hal: pertama, menghadirkan keadaan yang membuat peserta didik senang dan antusia (efek emosi); kedua, secara tidak langsung mengembangkan skill peserta didik dalam penggunaan teknologi, sebagai jawaban dalam menghadapi tantangan dunia di luar sekolah. Ketiga, teknologi bermanfaat dalam pembelajaran sebagai media pembelajaran dengan berbagai komponen dan utilitasnya. Hal tersebut dapat memudahkan dan menjadi efisien.

2. Emosi positif, kemampuan dalam memanfaatkan teknologi dan keterampilan dalam menggunakan sebuah program dan fasilitas dalam teknologi adalah sebuah kecakapan dan bekal yang baik bagi siswa dalam pengembangan kecakapan pengetahuanya melalui:

a. Pelatihan kecakapan membuat, meniru dan belajar,

b. Bereksperimen dengan latihan-latihan yang berbasis problem solving,

c. Membiasakan keadaan sekitar lingkungan belajar yang kontruktivis.

Menurut Hadisi \& Muna (2015) ada 9 prinsip yang harus dipahami oleh sekolah, guru dan siswa untuk mendukung pelaksanaan integrasi dalam pembelajaran, prinsip tersebut adalah:

1. Aktif: memunculkan reaksi siswa untuk terlibat secara aktif dalam proses belajar.

2. Konstruktif: memancing siswa untuk dapat memunculkan gagasan baru ke dalam pengetahuan baru melalui pengalaman yang diperoleh sebelumnya untuk mendalami rasa penasaran dalam benak siswa.

3. Kolaboratif: akan menjadi wadah untuk sebuah organisasi atau kelompok untuk saling kerjasama, bertukar ide, pengalaman dan saran sesama anggota.

4. Antusiastik: memacu siswa untuk menjadi aktif dan antusias untuk mencapai tujuan yang di maksud. 
5. Kontekstual: Memungkinkan kondisi belajar yang mengarah ke dalam proses belajar yang bermakna (real word) dengan pendekatan problem based dan casebased learning.

6. Dialogis: memacu prose kegiatan belajar yang selaras dimana ada sebuah proses sosial dan dialog yang mana siswa mendapatkan sebuah benefit dari komunikasi tersebut baik di dalam ataupun di luar ruang.

7. Reflektif: memungkinkan siswa menyadari apa yang telah dia pelajari dan menganalisa apa yang telah diperolehnyaa yang merupakan bagian dari proses pembelajaran itu sendiri.

8. Multisensory: Memungkinkan proses belajar di lakukan dengan berbagai modalitas belajar (multisensory) yang berupa video, audio, visual ataupun kinestetik.

9. High order thinking skills (HOTS) training: memacu siswa menjadi terlatih dalam kecakapan berpikir tingkat tinggi (seperti penyelesaian masalah dan memutuskan masalah) kemudian juga secara tidak sadar mengembangkan kemampuan "ICT dan media literacy".

Herry (2013) berpendapat untuk mewujukan masyarakat berbasis pengetahuan diperlukan upaya-upaya, yaitu: memastikan bahwa setiap orang mampu memperoleh kemampuan Teknologi Informasi dan Komunikasi dan meningkatkan kompetensi lain dengan TIK dan juga untuk berperan dalam kehidupan masyarakat; menentukan capain dari pembelajaran bagi emansipasi dan pemberdayaan; dan menghidupkan literasi Teknologi Informasi dan Komunikasi yang meruapakan bagian berkelanjutan dari long life education.

\section{B. METODOLOGI}

Pada penelitian ini, melalui pendekatan deskriptive kualitatif untuk menganalisis pemanfaatan dan penggunaan teknologi informasi dan komunikasi dalam kegiatan pembelajaran pada mata kuliah Ilmu Teknologi dan Masyarakat di IAIN Syekh Nurjati Cirebon. Selain peran tekologi dalam pembelajaran, pada mahasiswa IAIN Syekh Nurjati Cirebon Jurusan IPS Semester 4, peneliti juga menganalisa peran teknologi terhadap masyarakat.

Penelitian Kualitatif yang merupakan metode yang dipakai untuk meneliti pada kondisi objek yang alamiah. Sugiona (2009) menyatakan bahwa pendekatan 
kualitatif dalam penelitian dengan cara menyamakan antara kenyataan empirik dengan pengetahuan atau teori yang digunakan dengan memakai metode deskriptif. Terkait dengan data yang akan digunakan, peneliti menggali data dari informan. Hamidi (2010) menyatakan informan (sumber data pada penelitian ini) adalah seseorang yang dipercaya cakap oleh peneliti untuk menyampaiakn informasi secara detail baik terkait dirinya, terutama individu lain, keadaan, dan situasi terkait dengan data penelitian. Sumber informasi/Informan dalam penelitian ini adalah mahasiswa semester 4 Tadrsi Ilmu Pengetahuan Sosial Fakultas Ilmu Tarbiyah dan Keguruan IAIN syekh Nurjti Cirebon.

\section{HASIL DAN PEMBAHASAN}

Keterampilan belajar mengajar abad ke-21 menggaris bawahi kebutuhan untuk beralih dari metode yang berpusat pada guru (teacher centered learning) untuk lebih berpusat pada siswa (student centered learning). Lingkungan pembelajaran aktif dan kolaboratif difasilitasi oleh TIK berkontribusi pada penciptaan populasi mahasiswa berbasis pengetahuan. Pembelajaran yang terintegrasi dengan teknologi merupakan alternatif yang baik untuk menjawab kebutuhan dan tantangan yang ada dalam pembelajaran.

\section{Peran teknologi dalam pembelajaran.}

Pembaharuan dalam sebuah proses pembelajaran sangatlah dibutuhkan. Pengembangan dan transformasi dalam pendidikan khusunya dalam proses pembelajaran sebuah keniscayaan, dari sebuah sistem dan proses pembelajaran yang konvensional yang dianggap sudah tidak relevan dengan perkembangan zaman yang secara masif dan intensif terus berkembang yang di pengaruhi oleh kemajuan tyeknologi. Pembelajaran yang dilakukan sebagaimana biasanya melalui tatap muka ataupun melalui jejaring media lainya namun di bubuhi sebuah media teknologi sebagai mediator untuk transfer ilmu pengetahuan.

Teknologi informasi dan komunikasi yang dimanfaatkan dalam kegiatan pembelajaran dengan maksud untuk meningkatkan efektifitas dalam proses kegiatan pembelajaran yang diharapkan berpengaruh juga pada hasil siswa serta kompetensi dan mutu peserta didik secara individu dalam pemanfaatan teknologi secara tepat dan bermanfaat. 
Teknologi yang bisa membantu proses pembelajaran di antaranya: powerpoint, multimedia presentasi, video editor, email, WAG discussion dan masih banyak media yang lainnya. Dari data yang diperoleh dapat di katakan bahwa penggunaan multimedia presentasi cukup banyak dan tinggi. Penyampaian materi secara presentasi adalah salah satu cara dan metode dalam pembelajaran dan, pemanfaatan multimedia untuk presentasi menjadi pilihan terbanyak dibandingkan dengan metode lainnya. Penggunaan multimedia untuk presentasi sangat berpengaruh yang cukup signifikan, hasil juga menunjukan bahwa menggunakan media pembelajaran khusunya presentasi bisa meningkatkan hasil belajar peserta didik. Pemanfaatan multimedia untuk presentasi dalam kegiatan pembelajaran bermaksud untuk mengakomodir secara maksimal pemanfaatan elemen indra yang ada pada peserta didik baik yang audio, visual, ataupun audio visual.

Pemanfaatan teknologi untuk presentasi dimanfaatkan oleh guru, dosen maupun siswa untuk menyampaiakan dan mempresentasikan materi kegiatan belajar maupun tugas-tugas yang telah diberikan. Melalui pemanfaatan teknologi untuk presentasi pendidik dan peserta didik ataupun dosen dan mahasiswa akan membantu dalam hal efisiensi waktu, hal tersebut sisebabkan materi yang disampaikan tidak perlu lagi di tulis di papan tulis untuk di sampaikan kepada peserta didik selaian itu juga peserta didik mempunyai lebih banyak waktu untuk berkomunikasi, berdialog bahkan bertanya terkaiat materi yang di sampaikan.

\section{Respon mahasiswa terhadap penggunaan teknologi dan penerapanya} dalam pembelajaran.

Sebuah proses penguatan nilai dan karakter dalam sebuah pembelajaran Ilmu Teknologi dan Masyarakat dapat diwujudkan melalui proses pembudayaan dalam sebuah lingkungan dan lembaga pendidikan dengan mengintegrasikan sebuah pendidikan nilai dan karakter dalam rencana bahan ajar sehingga nilai dan karakter seperti pembiasaan, penugasan, dan keteladanan yang merupakan bagian yang tidak terpisahkan dan integrasi yang secara terus menerus menjadi bagian yang dipelajari, dipahami, diamalkan dalam kehidupan sehari-hari. Strategi mengaplikasikan dan peningkatan di 
dalam bidang ilmu teknologi diharapkan selalu di integrasikan dalam proses belajar mengajar untuk memacu peningkatan kecakapan siswa dalam pemanfaatan teknologi. Elemen-elemen yang perlu di tingkatkan adalah: akses dari pemanfaatan teknologi, output dari pemanfaatan teknologi, dan dampak dari pemanfaatan teknologi. Pembelajaran dengan menggunakan teknolgi yang terprogram dan sistematis dapat memacu pada level pembelajaran berbasis teknologi, dimana pada masing-masing level ditinjau dari faktor: infrastruktur, sumber daya manusia, konten, pembelajaran, serta kebijakan dan program.

Pembelajaran menggunakan teknologi digital memberikan peluang peserta didik untuk mencari sumber informasi yang lebih luas dengan mengakses internet baik di mesin pencarian seperti google, youtube, ataupun aplikasi yang terkait pembelajaran. Pembelajaran memanfaatakan teknologi digital merupakan 'setting' yang dapat memberikan rangsangan pada semua indera siswa dalam pembelajaran. Pembelajaran yang memberikan rangsangan pada semua indera siswa merupakan merupakan salah satu yang mempengaruhi motivasi. Proses pembentukan sikap dan keterampilan siswa sangat erat dengan kognitif (pengetahuan).

Data penelitian juga menunjukan bahwa mahasiswa merespon sangat positf terkait pembelajaran menggunakan media teknologi. Pembelajaran dengan menggunakan teknolgi membantu memudahkan dalam penyampaian baik oleh dosen ataupun mahasiswa. Selain itu juga mahasiswa merasa soft skill terkait penggunaan teknolgi semakin terasah.

Pengintegrasian teknologi digital dalam pembelajaran membuat proses pembelajaran lebih menarik, kreatif dan sumber informasi dapat didapat lebih banyak. Jadi media yang cukup digemari siswa adalah media yang bisa menggabungkan berbagai aspek yang berpengaruh juga dalam meningkatkan hasil belajar siswa. Media yang bisa menggabungkan teks, gambar, animasi, dan presentasi yang bisa menggabungkan hal tersebut.

\section{Peran teknologi dalam kehidupan masyarakat.}

Dalam bidang sosial masyarakat berbasis pengetahuan membawa lebih banyak akses ke informasi dan bentuk-bentuk baru interaksi sosial dan ekspresi 
budaya. Individu memiliki lebih banyak kesempatan untuk berpartisipasi dan mempengaruhi perkembangan masyarakat mereka.

Munculnya masyarakat berbasis pengetahuan dan penyebaran luas penggunaan TIK menghasilkan kebutuhan akan keterampilan digital baru dan kompetensi untuk pekerjaan, pendidikan dan pelatihan, pengembangan diri dan partisipasi dalam masyarakat. Meskipun ada risiko yang cukup besar bahwa kelompok-kelompok yang kurang beruntung dan orang-orang terpinggirkan tidak akan sepenuhnya mampu mengambil manfaat dari peluang baru yang ditawarkan oleh TIK, pengguna TIK yang kompeten adalah peserta didik pada umumnya dan pendidik pada khususnya. Oleh karena itu untuk mewujudkan masyarakat berbasis pengetahuan diperlukan upaya-upaya, yaitu: memastikan bahwa setiap orang mampu memperoleh kompetensi TIK yang diperlukan dalam masyarakat informasi dan memanfaatkan kecakapan lain melalui Teknologi Informasi dan Komunikasi dengan berpartisipasi dalam masyarakat; menetapkan tujuan pemanfaatan teknologi bagi masyarakat dan pemberdayaan, seperti kompetensi sosial, berpikir kritis, berbagi pengetahuan dan teknik kerjasama; dan menumbuhkan literasi teknologi yang harus dijadikan sebagai proses pembelajaran seumur hidup, karena masyarakat berbasis pengetahuan yang dinamis dan cepat berubah membutuhkan keterampilan yang terusmenerus harus diperbaharui. Dari data yang ada menunjukan masyarakat sudah aware terkait teknologi, baik terkait pekerjaan, pendidikan, dan ekonomi.

Terkait pertanian masyarakat sudah menggunakan bantuan teknologi baik di musin tanam atau panen. Pada bidang pendidikan masyarakat khususnya orang tua sebagain sudah mampu memanfaatkan sumber electronik untuk belajar bagi anak-anaknya. Dalam bidang ekonomi masyarakat sudah memanfaatkan teknologi untuk memasarkan produk agar terjangkau lebih luas lagi. Pada dasarnya teknologi bisa membantu meringankan beban pekerjaan masyarakat, baik di bidang pendidikan, komunikasi, pertanian, perkebunan dan berbagai aspek dalam kehidupan bermasyarakat lainya.

\section{KESIMPULAN}

Integrasi teknologi informasi yang berkembang di Indonesia masih berada dalam tataran implementatif dan adaptif seperti pemanfaatan teknologi ke dalam 
pembelajaran. Pemanfaatan teknologi dalam integrasi pembelajaran belum sampai kepada modifikasi, dan kreasi inovasi teknologi informasi. Pemanfaatan teknologi belum dapat dilakukan dengan maksimal. Pemanfaatan teknologi dalam kegiatan pembelajaran dapat meningkatkan kreativitas dan efektifitas dalam pelaksanaan proses pembelajaran yang akhirnya dapat meningkatkan hasil belajar siswa serta kualitas individu para siswa dalam hal pemanfaatan teknologi lebih bijak dan baik. Pembelajaran menggunakan teknologi digital memberikan peluang peserta didik untuk mencari sumber informasi yang lebih luas dengan mengakses internet dan aplikasi yang tersedia. Siswa juga dapat mengasah soft skill terkait terknologi yang sudah di miliki. Pengintegrasian teknologi digital dalam pembelajaran membuat proses pembelajaran lebih menarik, kreatif dan sumber informasi dapat didapat lebih banyak. Media yang di anggap mampu untuk membantu meningkatkan hasil belajar peserta didik adalah media yang dapat menggabungkan unsur gambar, teks, dan animasi. Dalam bidang sosial masyarakat, TIK menghasilkan kebutuhan akan keterampilan digital baru dan kompetensi untuk pekerjaan, pendidikan dan pelatihan, pengembangan diri dan partisipasi dalam masyarakat. Pada dasarnya teknologi bisa membantu meringankan beban pekerjaan masyarakat, baik di bidang pendidikan, komunikasi, pertanian, perkebunan dan berbagai aspek dalam kehidupan bermasyarakat lainya.

\section{Referensi}

Asrizal. (2013). Strategi Integrasi dan Design Perangkat Pembelajaran Sains Terpadu Berbasis ICT untuk Pembelajaran Siswa SMP. Seminar Nasional Pendidikan MIPA 2013.

Degeng, Nyoman Sudana. (2004). Teori Pembelajaran, Malang, Jawa Timur: UM Press.

Dodi Nandika, Gatot H. Priowirjanto, \& Soekartawi. 2007. Integrating ICT for better quality and values of education. http://www.seameo. org/vl/library/dlwelcome/publications/report/thematic/07forum42.pdf.

(Diakses, 24 Jan 2020). 
Hadisi, Muna. (2015). Pengelolaan Teknologi Informasi dalam Menciptakan Inovasi Model Pembelajaran E-Learning. Jurnal Al-Ta'dib Vol. 8 No. 1, JanuariJuni 2015.

Hamidi. (2010). Metode Penelitian Kualitatif Pendekatan Praktis Penulisan Proposal dan Laporan Penelitian. Cetakan ke-2. Malang: UMM Press.

Herry F. (2013). Integrasi Teknologi Informasi Komunikasi dalam Pendidikan: Potensi Manfaat, Masyarakat Berbasis Pengetahuan, Pendidikan Nilai, Strategi Implementasi dan Pengembangan Profesional. Jurnal Pendidikan Teknologi dan Kejuruan, VVolume 21, Nomor 3, Mei 2013

Hoyles, C., \& Lagrange, J.-B. (Eds.). (2010). Mathematics education and technology--Rethinking the terrain. New York, NY/Berlin, Germany: Springer.

Miarso, Yusuf Hadi. (2004), Menyemai Benih Teknologi Penddikan, Jakarta:Kencana.

Sugiyono, (2009). Memahami Penelitian Kualitatif. Bandung: Alfabeta.

Suyatno. (2016). Integrasi Teknologi Informasi dalam Pembelajaran Pendidikan Agama. https://bdksemarang.kemenag.go.id/integrasi-teknologi-informasidalam-pembelajaran-pendidikan-agama-islam/.

Suryadi, Ade. (2007). Pemanfaatan ICT dalam Pembelajaran. Jurnal Pendidikan Terbuka dan Jarak Jauh, Volume 8, Nomor 1, Maret 2007, 83-98.

Tekege Martinus, (2017). Pemanfaatan Teknologi Informasi dan Komunikasi dalam Pembelajaran SMA YPPGI Nabire. JURNALFATEKSA: Jurnal Teknologi dan Rekayasa, Volume 2, No.1 Juli 2017, hal.40-52.

Wikipedia, Information Technology, 2009, http://en.wikipedia.org/wiki/ Information technology, h. 1.

Woodbridge, J. (2004). Technology integration as a transformation teaching strategy. Diambil 5 Oktober 2019, dari www.techlearning.com. 